\title{
The impact of crime and the fear thereof on the nature and use of public space in the capital city of South Africa
}

\author{
LANDMAN, Karina ${ }^{1}$
}

1University of Pretoria, Pretoria, karina.landman@up.ac.za

\begin{abstract}
Resumo
Níveis de insegurança, criminalidade e desigualdade permanecem muito altos nas cidades brasileiras e sul africanas. Consequentemente, os habitantes mais ricos se retraem para espaços coletivos protegidos por muros e cercas. Como resultado, tem havido um crescimento de muitos espaços semipúblicos em shopping centers e condomínios. Isso levanta questões sobre a mudança do espaço público e o impacto do crime e do medo no uso desses espaços. Esta discussão mostra como a forma e a função de diferentes espaços na capital da África do Sul, Pretória, mudaram em várias partes da cidade em razão de negligência, revitalização ou privatização e como isso moldou a experiência dos usuários em relação ao crime e ao medo . $\mathrm{O}$ artigo defende uma leitura mais matizada da transformação do espaço público. Em primeiro lugar, reconhece que, em cidades em rápida mudança em países em transição, ainda pode haver necessidade de diferentes tipos de espaços públicos, inclusive aqueles em condomínios. Em segundo lugar, embora a segurança seja uma grande preocupação entre usuários do espaço público, isso não implica que condomínios sejam a única solução para um espaço público seguro. Portanto, abordagens alternativas devem ser consideradas.
\end{abstract}

Palavras-Chave: crime, medo, espaço público, condomínios, África do Sul.

\begin{abstract}
Levels of insecurity, crime and inequality remain very high in Brazilian and South African cities. Consequently, wealthier residents retreat to protected common spaces behind walls and fences. As a result, there has been a growth of many quasi-public spaces in shopping malls and gated communities. This raises questions regarding the change of public space and the impact of crime and the fear thereof on the use of these spaces. The discussion shows how the form and function of different spaces in the capital city of South Africa, Pretoria, have changed in various parts of the city through neglect, revitalization and privatization and how this have shaped the experience of users in relation to crime and fear. The paper argues for a more nuanced reading of the transformation of public space. Firstly, it recognizes that in rapidly changing cities of transitional countries there may still be a need for different types of public spaces, including those in gated communities. Secondly, although safety is a major concern among users of public space, it does not imply that gated communities offer the only solution to safe public space. Therefore, alternatives approaches should be considered.
\end{abstract}

Key-Words: Crime, Fear, public space, gated communities, South Africa. 


\section{Introduction}

Worldwide, in constantly dynamic cities, public spaces are also changing. This is also true in Brazil and South Africa. There are many similarities between the urban landscapes and spatial patterns of cities in these two countries. After political transition from an authoritarian rule, both countries experienced high levels of insecurity, crime and a continuation of segregation practices exacerbated by social instability and high levels of inequality (LANDMAN, 2002). Despite progressive policies towards greater equity and integration in the democratic era, levels of crime and insecurity remain high in many Brazilian and South African cities (SHAW 2002; MESQUITA NETO, 2001). Consequently, those who can afford it, try to avoid traditional public space and retreat to controlled and secured spaces within shopping malls and gated communities.

This raises many questions about the impact of crime and the fear on the transformation of public space and the implications for more inclusive spaces in Brazilian and South African cities. This paper offers new insights to the ongoing segregation-integration conundrum.

As part of ongoing work on the transformation of public space in South Africa, we investigated the nature and use of different types of spaces in various parts of the capital city of South Africa, Pretoria. We also examined the experiences and perceptions of the users of these spaces. Although numerous factors were mentioned that discouraged the use of various public spaces, we were struck by the constant regularity in which crime and the fear of crime were raised as a major concern by public space users in the city.

In this paper, I examine the form and the function of a number of contemporary public spaces in the city and the impact of crime and the fear on the use of these spaces in the light of ongoing conversations about urban segregationintegration in South African and Brazilian cities. The paper argues for a more nuanced reading of the transformation of public space. The discussion indicates that crime and the fear of crime remain serious concerns and influence the levels of comfort and feelings of security within traditional public spaces. The search for greater safety and security, therefore, does not simply signify an automatic quest for segregation or exclusion, although some may interpret these as one way of addressing crime. Consequently, some people opt for common open space in protected enclaves. However, while safety is a major concern among both existing and potential public space users, it does not imply that gated communities offer the only solution to safe spaces. The paper points towards alternative integrated approaches to address crime in the built environment that move away from the more pronounced segregation practices. The analysis is part of an ongoing conversation about the continuation of imposed segregation practices in post-colonial and authoritarian countries and its re-emergence through contemporary spatial practices such as gated communities (MESQUITA NETO, 2001; CALDEIRA, 2000; KOWARICK, 2001; LANDMAN, 2002; SHAW, 2002; LEMANSKI et al. 2008).

\section{Study Background}

The paper draws on findings from multiple case studies on different types of public spaces in various parts of the City of Tshwane, which is the municipal area that includes the capital city of South Africa, Pretoria. As part of a broader study on the transformation of public space in South Africa, case studies were conducted between 2012 and 2016 to investigate different drivers contributing to the transformation of space, as well as the impact and implication of these changes. These included a range of case studies from various cities across South Africa and from different parts of these cities, including Central Business Districts, inner and peripheral suburbs and cases from former African township areas. This paper only focusses on public spaces from the City of Tshwane.

\subsection{Changing cities in South Africa}

Similarly to Brazil, South Africa is regarded as a transitional country in a political sense, as both countries have shifted from an authoritarian rule to a democracy at the end of the twentieth century: Brazil in 1988 and South Africa in 1994. Consequently, their cities have experienced 
numerous changes, including increased levels of urbanisation and crime, as well as spatial transformation.

Prior to 1994, South African cities were shaped by the Apartheid ideology focusing on separate development, where different population groups were forced to stay in specifically designated areas due to the Group Areas Act of 1950. As a result, "South Africa is considered as one of the most heterogeneous, complex and divided societies characterized by deep-rooted racial and cultural differences" (BORNMAN, 2005, p. 5). Consequently, post-apartheid policies emphasize the need for spatial integration and social inclusion. However, this remains a challenge given the high levels of urbanisation and crime.

There has been a huge increase in urbanization in the major cities. Since the removal of the apartheid-era constraints on the free movement of black people, South African cities have grown rapidly through a combination of natural growth and in-migration from rural South Africa and neighbouring countries. From 2001 to 2011, the population in the metropolitan cities grew by $25 \%$ compared to $10 \%$ in the rest of the country (TUROK and BOREL-SALADIN, 2014). In 2011, more than 60 percent of the population in South Africa lived in cities, creating a greater demand for infrastructure, affordable housing and spaces for recreation. Yet, in the midst of increased urbanization, South African cities continue to struggle with high levels of inequality and unemployment (NATIONAL DEVELOPMENT PLAN, 2011). Income inequality have changed little since 1994 despite the introduction of social grants and partly because job creation did not keep up with the number of people needing jobs (KEETON, 2014). Consequently, unemployment remains high at $25,2 \%$, while the levels of poverty (per headcount is at 56\% (2012 Household Survey, Statistics SA).

Crime also remains a major challenge. Recent reports indicate that the past few years (20122015) not only witnessed very little crime reduction, but also threatened to deplete the steady gains of the previous eight years after the initial surge in the late 1990s. For example, while theft out of motor vehicles (-2.1\% per annum) and residential burglaries $(-2.3 \%)$ have decreased in
2014/2015, particularly due to increased target hardening efforts, there has been an increase in house robberies (5.2\%), car hijacking (14.2\%) and aggravated robbery (9\%) (DE KOCK, 2015, p. 10-13). In addition, the National Victims of Crime Survey (VOCS) done by the Statistics SA from 2012 to 2015 have reported an increase fear of residential burglaries and street robbery from the public (VOCS). It has also been indicated that in 2012 the murder rate in South Africa was 37,3 murders per 100.000 people, nearly five times the global murder rate of 7,6 murders per 100.000 (BREETZKE et al, 2013).

Growing levels of insecurity and major changes within cities have contributed to an increasing demand for various types of gated communities in the country. In response to crime and various other types of insecurities, some people choose to live in gated communities, which can broadly be defined as a physical area that is fenced or walled off from its surroundings (Landman 2005). Access to these areas are either prohibited or controlled by means of gates and/or booms. In many cases it refers to a primarily residential area with restricted access and privatized communal spaces, but may also include controlled access areas for business, retail or recreational purposes (LANDMAN, 2006).

However, at the same time traditional public spaces are also changing. These public spaces include soft open spaces such as parks and hard spaces such as squares and streets.

\subsection{Selected public spaces}

This discussion is centered on eight public spaces within the broader Pretoria area that represent various part of the city, including the CBD (Central Business District), inner and peripheral suburbs, former township areas and gated communities in the peripheral suburbs. This is summarised in Table 1, while the location of the spaces is depicted in Figure 1.

Table 1: Selected Public Spaces

\begin{tabular}{ll}
\hline Part of the city & Public Space \\
\hline CBD & Church Square \\
& Burgers Park \\
Inner suburbs & Springbok Park \\
Peripheral suburbs & Jimmy Aves Park
\end{tabular}


Former township areas

Kalefong Park

Solomon Mathlangu

Square

Gated communities (in peripheral suburbs)
Common space in The Wilds

Common Space in Mooikloof Ridge

Researchers approached a variety of users in each space who were willing to participate and to allow for age, gender, population, etc. variation. However, while interviewees also included some of the more marginalised people, the data may not be fully representative of all users, such as the drug dealers or homeless people who

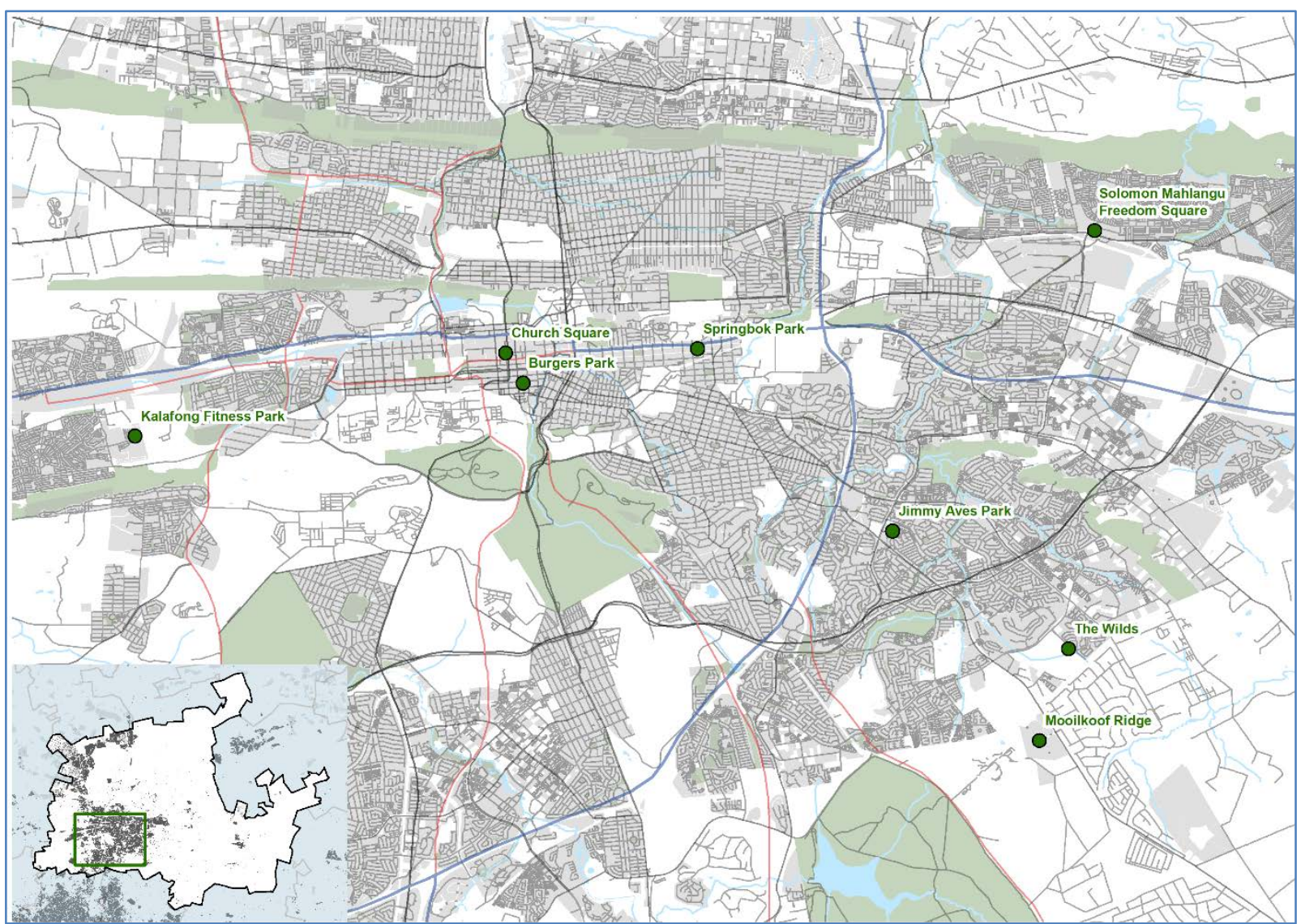

Figure 1: Location of the selected public spaces in the City of Tshwane (Source: Map produced by Darren Nel)

\subsection{Methodology}

Various methods were utilised to understand the nature and use, as well as the perceptions of users, regarding the nature and use of these public spaces. These methods included spatial analysis, participant observation and semistructured interviews. The aim of the spatial analysis was to determine the nature of the physical form, while the purpose of the participant observation was to determine the function of the space. The semi-structured interviews set out to determine the perceptions of users about the use of the spaces. At least fifteen respondents from each space were asked what encouraged and discouraged the use of these spaces. often avoided contact with unknown people. Numerous Town and Regional Planning Students from the University of Pretoria have been instrumental in assisting with data collection for various case studies.

\section{Changing spaces in Tshwane and the impact of crime and the fear thereof}

The form and function of public spaces have changed in the past few years due to neglect, revitalisation and privatisation. Many spaces in the CBD of Pretoria and some of the inner city areas have deteriorated due to a lack of management and maintenance. The neglect of these 
spaces are often characterised by litter, graffiti and broken windows or lights and signs of unlawful behaviour such as urinating in the parks (LANDMAN, 2016a). At the same time, the use of these spaces is also changing. Green open spaces with protective vegetation are also used by the homeless at night, for example Burgers Park, Magnolia Dall and Vening Park.

Yet, while some spaces have experienced various levels of neglect, others have been revitalised. The local authority have responded with urban upgrading projects to improve the condition of the built environment in previously marginalised or former townships areas. This included projects to revitalise public space and contribute to the quality of life of many poorer people in these areas, for example the Kalefong Fitness Park in Attridgeville and the Solomon Mathlangu Square in Mamelodi. The Kalafong Fitness Park was officially opened in 2013 and developed as part of Tshwane's "Two Parks per Ward Programme". The aim was to enhance the image of amenities and the landscape to make the city a more attractive place and implement the vision of the Tshwane 2055 Strategy towards a more resilient, inclusive and liveable city (New Fitness Park, 2013). Safety is a key priority to achieve this. The new Solomon Mathlangu Square was officially opened in 2015 by the then Major of the City of Tshwane, Ramokgopa, who stated that the Memorial Square was upgraded to inspire, educate and offer opportunities to the local community (Solomon Mathlangu Square, 2015).

However, in reaction to the deterioration and neglect of many public spaces, the private sector have responded through the privatisation of public space. This includes the growth of quasipublic spaces in shopping centres and the inclusion of common open spaces for recreation in gated developments. As part of the continuous evolution of public space, there has been an emergence of a new type of controlled outdoor space that tends to reflect some of the characteristics of more traditional open spaces, but operates very differently within the tightly secured boundaries of shopping malls and reflects strong patterns of consumption (LANDMAN, 2016b). Controlled open spaces have also become characteristics of gated communities, and particularly larger security estates. These are new private developments that mainly occur on the periphery of large metropolitan areas in South Africa and include various land uses related to a specific type. The subtypes range from lifestyle estates to smaller gated townhouse complexes and non-residential gated office or commercial parks (LANDMAN and BADENHORST, 2014). These secure developments often include open space for recreational purposes, for example the parks in The Wilds and Mooikloof Ridge. These changes also tend to influence the experience of the users of these spaces in terms of crime and the fear of crime as related to both elements of form and function.

\subsection{Inner city and suburban public spaces} and the perceptions of crime and fear thereof The four selected public spaces in the CBD and traditional suburbs vary in form. Church square is one of the oldest open spaces in the city and is centred around a statue of a former president of the late eighteen century, Paul Kruger (Figure 2). It includes four pathways and the space is demarcated through a low chain (Figure 3). The space is surrounded by older institutional buildings, including the Palace of Justice, Old Reserve Bank, General Post Office, Capitol Theatre and the Mint Building. The space is well used for a variety of activities, ranging from those resting under the trees, or selling goods, to people using the free Wi-Fi and listing to lay preachers. It is also a popular venue for public protests.

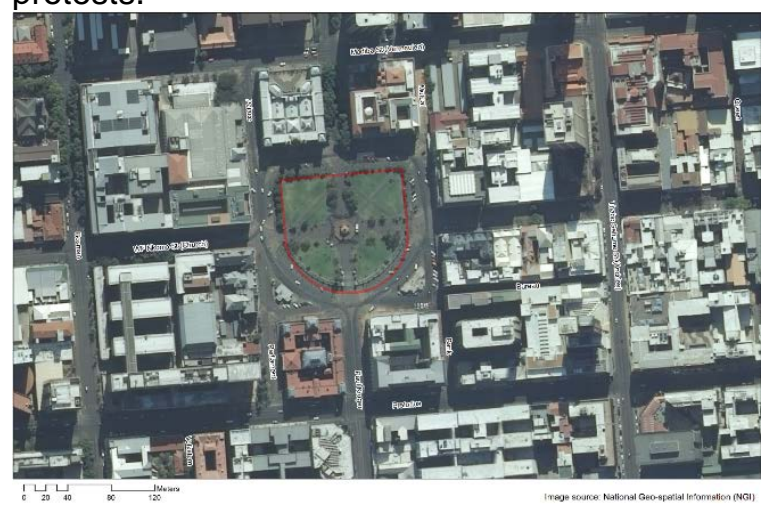

Figure 2: Form of Church Square (Source: Map produced by Darren $\mathrm{Nel}$ ) 


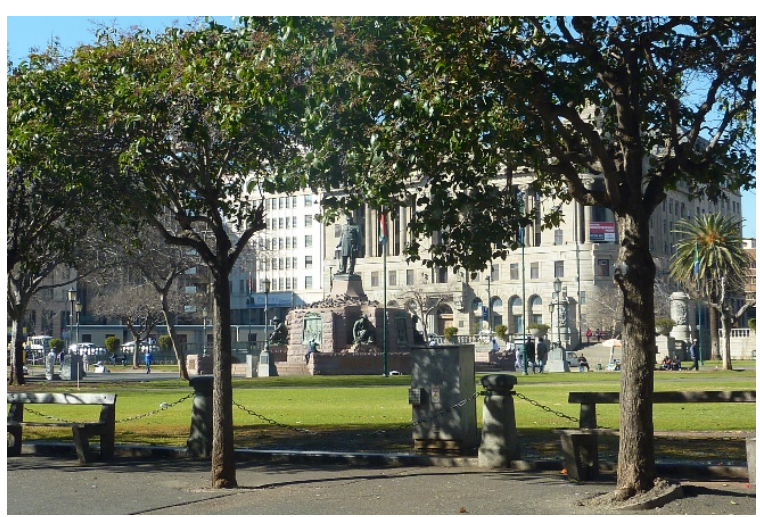

Figure 3: View of Church Square (Source: Author)

Burgers Park, a 4 ha Victorian park and Botanical garden, is located south of Church Square.

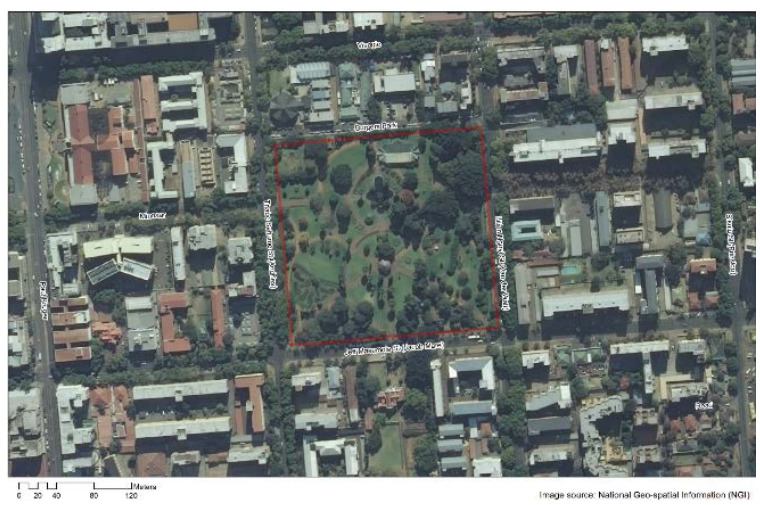

Figure 4: Form of Burgers Park (Source: Map produced by Darren Nel)

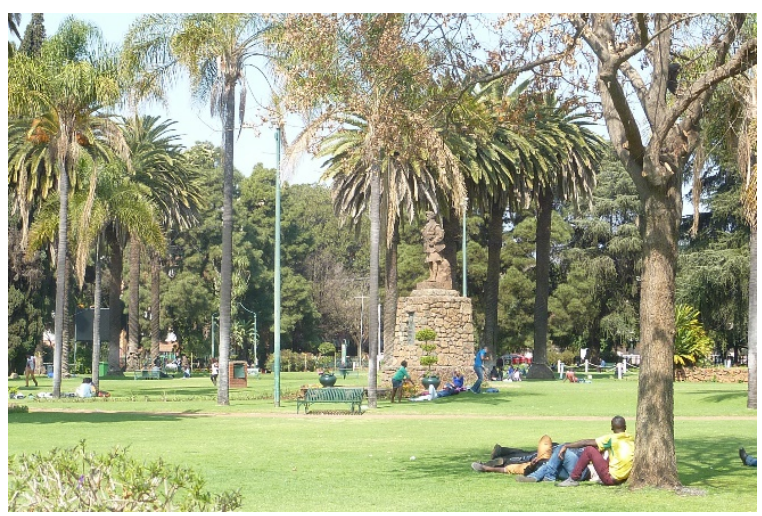

Figure 5: View of Burgers Park (Source: Author)

The park is surrounded by various high-rise apartment blocks and hotels. There is a low fence on the boundary with several organic walkways inside (Figure 4). Amenities include a band stand, pavilion, floranium, play park for children and covered pergola, while the Scottish War Memorial, the statue of Pres Burgers and the Memorial tree offer a strong sense of history. The natural beauty is strengthened by the old trees and a wide range of other vegetation. The park is extensively used for relaxation, reading, eating, playing ball, playing on the children's equipment and just for general social interaction.

Springbok Park is located east of Church Square in one of the older inner city suburbs. The park is surrounded by low to higher-rise office and apartment buildings (Figure 6). The boundary is demarcated by a wall and includes several entrances that lead to curving walkways with brick paving.

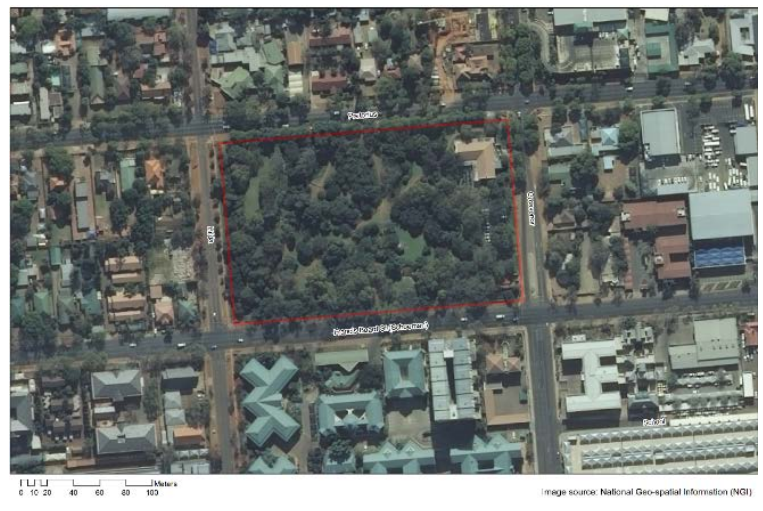

Figure 6: Form of Springbok Park (Source: Map produced by Darren $\mathrm{Nel}$ )

Structures include a gazebo, stone stairs and a bridge over a small stream, a restaurant in the north-east corner and toilet facilities in the south east corner. The main feature is the luscious vegetation and water features, including a larger and smaller pond connected to the stream.

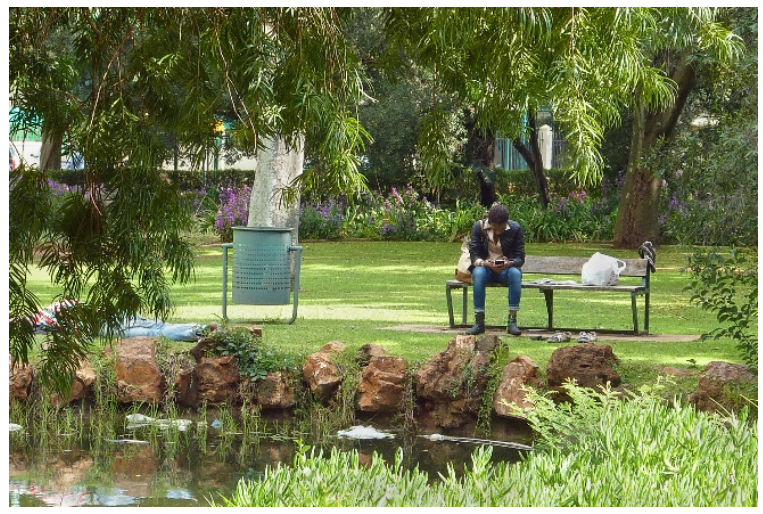

Figure 7: View of Springbok Park with the pond in the foreground (Source: Author)

Jimmy Aves Park is a more suburban park located further out in Garsfontein and is surrounded by suburban houses, a townhouse complex, old age home, fitness centre and car dealerships. There is no formal design or walkways, but a few footpaths across the grass. There is a tennis club with courts in the north and a play space for children. A few trees are scattered on 
the site. The park is utilised more during the weekends, with people walking their dogs, others relaxing under the trees or for church services on Sundays.

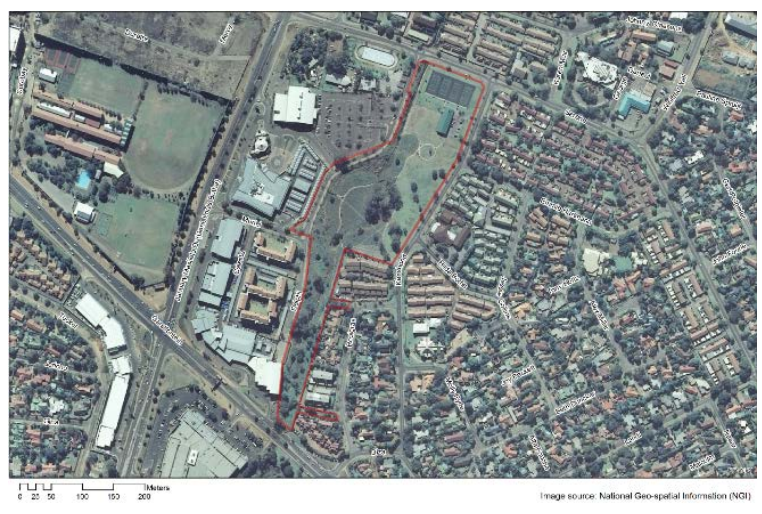

Figure 8: Form of Jimmey Aves Park (Source: Map produced by Darren Nel)

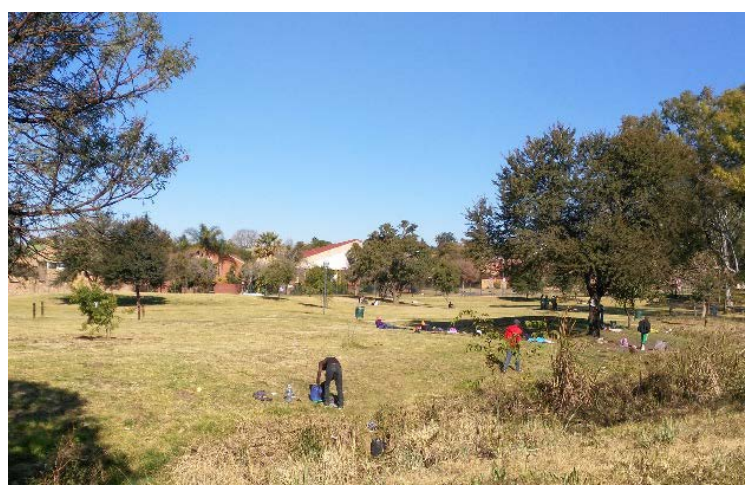

Figure 9: View of Jimmy Aves Park (Source: Author)

The perceptions of crime and fear of crime varied in these public open spaces. Users in both Church Square and Springbok Park stated that the presence of criminal activities discouraged the use of the space. This mostly referred to drug dealing. The presence of drug dealers made the female users feel unsafe and some asked for the presence of security guards. In Springbok Park, researchers saw informal hidden transactions being made, while younger males would communicate via hand signals that drugs were available. A few ladies sitting on the grass commented that they were offered some pills by the "nyaope guys". Nyaope is a highly addictive and dangerous street drug in South Africa and is commonly considered to include heroin, dagga, anti-retroviral drugs, milk powder, rat poison and pool cleaner. The drug dealers are also suspected of being involved in muggings. During one of the visits the researcher saw a man running towards the restaurant, stating that someone tried to steal his laptop. Users in Church Square commented that the opportunities for crime were increased by the presence of broken lights, while those in Springbok Park attributed it to the dense vegetation and lack of maintenance in the park.

A common theme that emerged in all four public spaces was the fear of crime associated with a lack of maintenance and the presence of homeless people. In Burgers Park, respondents commented on the lack of maintenance in some parts that discouraged use. Homeless people utilise the park during the evening and sleeps under the dense vegetation at the back of the Florarium, where their clothes can be seen under the trees. Similar issues about a lack of maintenance were raised in Church Square where one respondent commented that the square was not clean due to the "hobos that have turned the place into their toilet". In Springbok Park, the stream was polluted and card boards were visible under the trees with blankets, pillows and other belongings lying around.

Respondents commented about alcohol and other substance abuse. While the northern part of Jimmy Aves Park were visible from the surrounding streets, the southern part was more Pres. Burgers densely filled with vegetation around the stream and less visible from the surrounding townhouse complexes. This part was utilised by homeless people and hence mostly avoided by regularly park users. Some of the respondents referred to muggings that have taken place in the park and therefore considered the use of the park unsafe after dark and early in the mornings. In addition, users of Jimmy Aves park also complained about alcohol abuse in the park, which contributed to the fear of crime.

\subsection{Revitalised public spaces and the per- ceptions of crime and fear thereof}

The two selected public spaces in the former marginalised townships reflect significant physical interventions. The Kalefong Fitness Park is located in the middle-income area in Attridgeville and has a formal design with paved walkways and low walls to demarcate areas on the slope (Figure 10). 


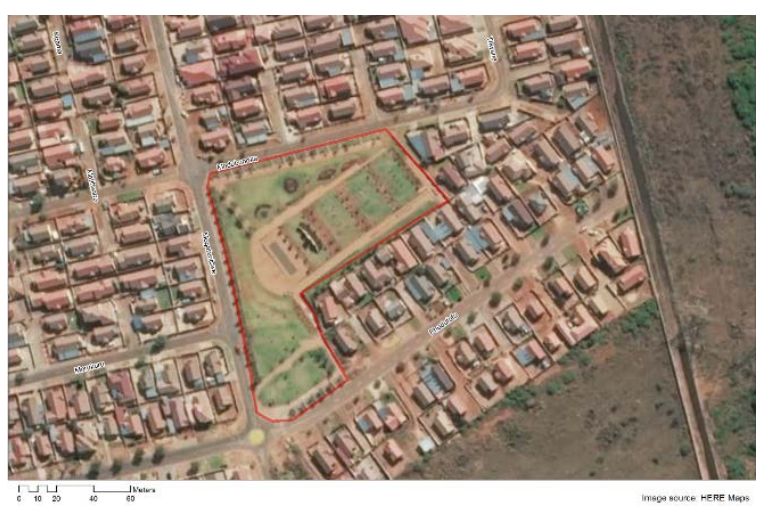

Figure 10: Form of Kalafong Park (Source: Map produced by Darren $\mathrm{Nel}$ )

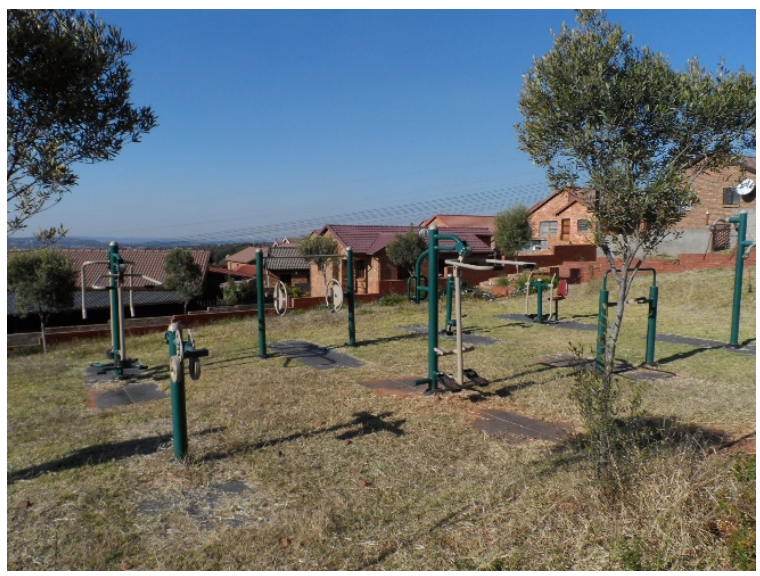

Figure 11: View of Kalefong Park towards the gym equipment (Source: Author)

The attractions include an amphitheatre, children's play area, outdoor fitness area with gym equipment, wall climbing and parking facilities. There is attractive landscaping, low walls and long and continuous walkways. However, there is a lack of drinking water, lighting, formal seating and ablution facilities. People utilise the park for relaxation, for children to play and for exercising.

Solomon Mathlangu Square is located in the centre of Mamelodi next to Tshamaya Road and opposite the Denneboom Station. As part of the upgrade, it was necessary to redesign the square to offer protection from the busy road, reorientate the statue to face the park, provide lighting around the square for safety and ablution facilities. The park is fenced off and the entrance to the park is from the pedestrian walkway on the eastern side that serves to connect the shopping mall to the north and the Denneboom Station to the south of the park (Figure 12). The park has a formal design based on two formal paths leading from the statue to the entrance and amphitheatre and a curving walkway criss-crossing these.

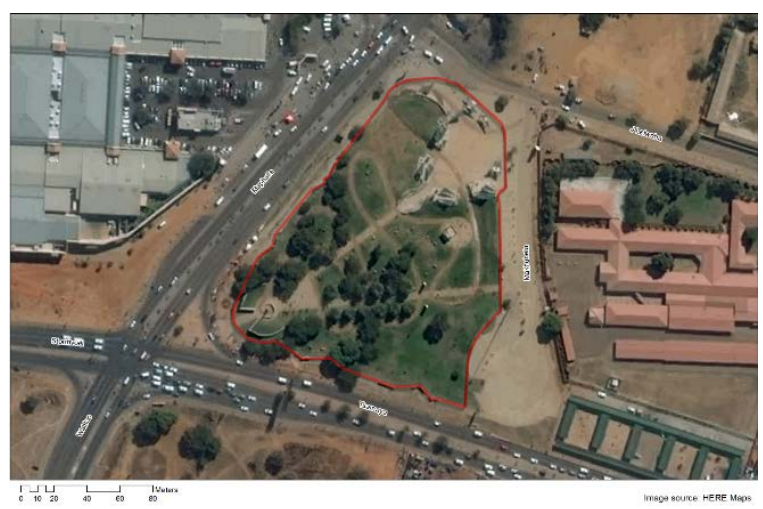

Figure 12: Form of Solomon Mathlangu Square (Source: Map produced by Darren $\mathrm{Nel}$ )

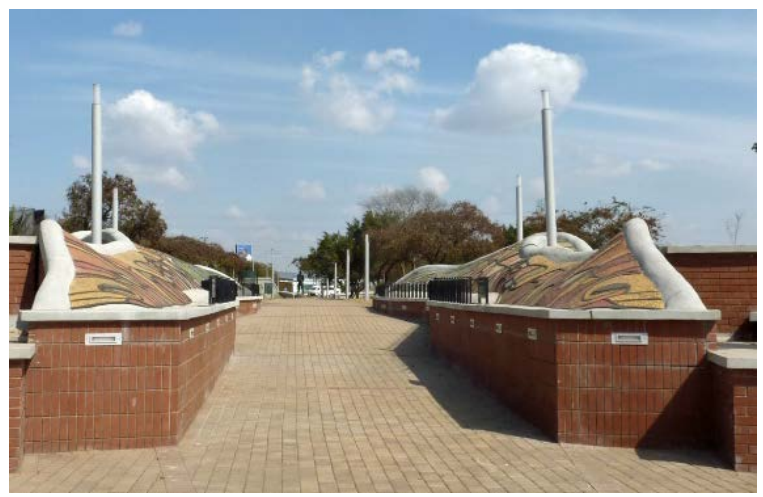

Figure 13: View of Solomon Mathlangu Square with the statue in the background (Source: Author)

The major attraction is the statue of Solomon Mathlangu - struggle hero - who was captured and hanged as a young boy of sixteen for his role in fighting the Apartheid Government. Ironically, however, since it has been upgraded, the park is locked by the local authority and only opened for special occasions such as music festivals due to a fear of vandalization and crime. Security guards man the entrance to the park.

There is, however, a lot of public life around the park. The pedestrian walkway adjacent to the park is utilised extensively. People stop and socialise along the route and come there to take pictures of people in front of the park. Two types of users frequent the space. They can be described as commuters and irregular users. The first group only passes through the space en route to the Denneboom Station or the Shopping Complex and sometimes stop to buy from the 
informal traders. The second group tend to stroll through the space and take time to buy goods from the traders or to engage in conversation.

The perceptions of crime and fear of crime varied in these two public open spaces. Respondents from the Kalefong Fitness park complained about the lack of lighting and mentioned that users have to leave at dusk due to a fear of crime. At night, pedestrians were also forced to take the long route around the park to benefit from the streetlights as they feared for their life and possessions. When asked if there were any crime cases reported that occurred in the park, the answer was negative. Yet, users maintained that crime exists there. As the Solomon Mathlangu park is locked, access is restricted and people are not free to use it. Previously, before the revitalisation of the park, the park was freely accessible. Interviews with users of the pedestrian walkway just adjacent to the park revealed a level of animosity about this. Some of the traders remarked that the park should never have been upgraded as it resulted in a loss of a major amenity. Others were of the opinion that the physical intervention contributed to the aesthetic value of the area but as it is locked, it cannot be of benefit to the community. Even the ablution block that faces the pedestrian walkway, is locked. The pedestrian walkway is, however, considered a safe space as there is always people moving through or others trading within the space.

\subsection{Privatised public spaces and the percep- tions of crime and fear thereof}

The two selected common open spaces in the security estates varie in terms of form and function. The two estates are located in peripheral suburbs in the east of the City of Tshwane and can be considered as medium sized estates. Mooikloof Ridge consists of 30 complexes or groups of cluster housing, while The Wilds comprises both single standing houses and cluster housing. The common open space in Mooikloof Ridge estate is located in the centre, relatively large and includes many facilities such as tennis and squash courts, a small golf course, a clubhouse and barbeque area, swimming pools, a soccer field and a park with vegetation and play space for children (Figure 13). There are wellstructured roads and pedestrian walkways and ample parking areas next to the entertainment areas.

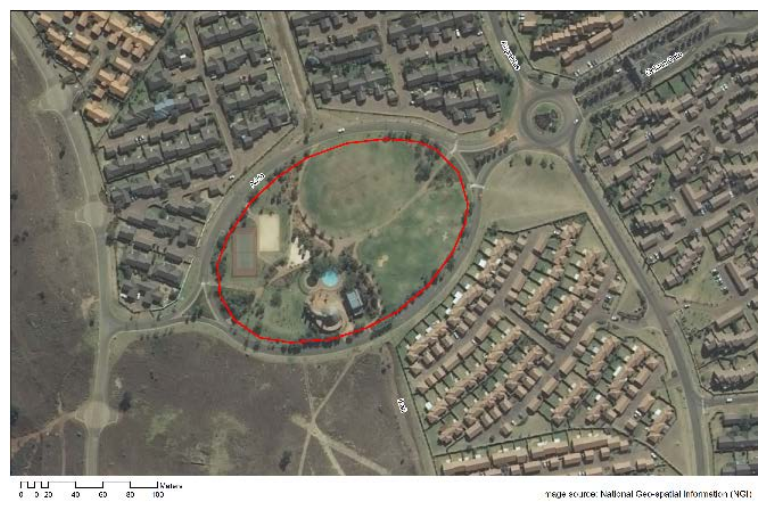

Figure 14: Form of common open space in Mooikloof Ridge (Source: Map produced by Darren Nel)

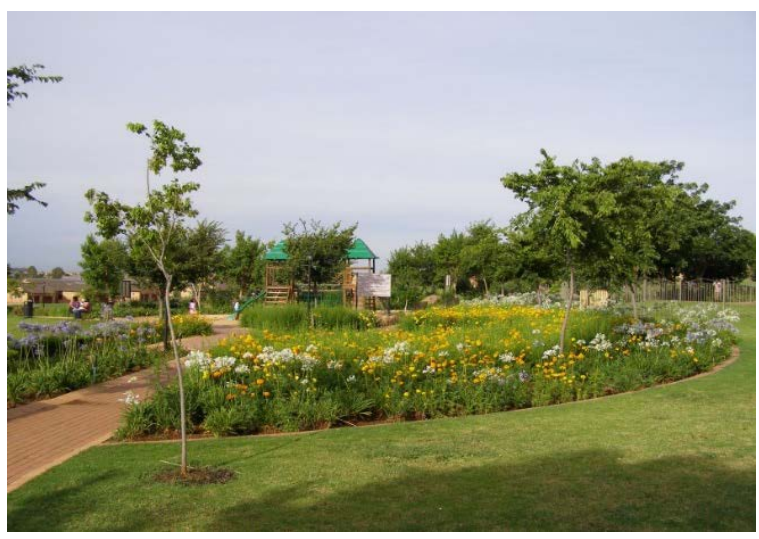

Figure 15: View of the park area in Mooikloof Rigde (Source: www.mooikloofridge.com).

Residents from the estate and their visitors utilise the common open space and facilities for socialising and to barbeque, for children to play, to relax and to promote a healthy lifestyle. The management of the estate organises a variety of events such as fund days for children with jumping castles and motorised fun fare rides and Boy Scout events.

The common open space in The Wilds is much smaller and only includes a large club house, a swimming pool, a lapa with barbeque facilities, a jungle gym for children and two tennis courts. The clubhouse includes the estate management office, ablution facilities and squash courts. The common open space is situated in the centre of the estate, but as only half of it has been developed, it is currently on the edge of the built-up area (Figure 16). There is a lack of seating in 
the park area and limited vegetation. Residents of the estate and their visitors utilise this space for relaxation on the lawn, sporting activities and socialisation.

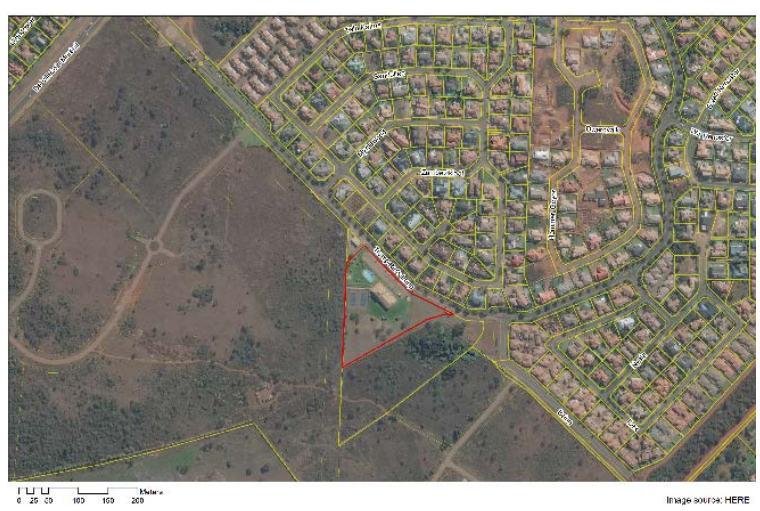

Figure 16: Form of common open space in The Wilds (Source: Map produced by Darren Nel)

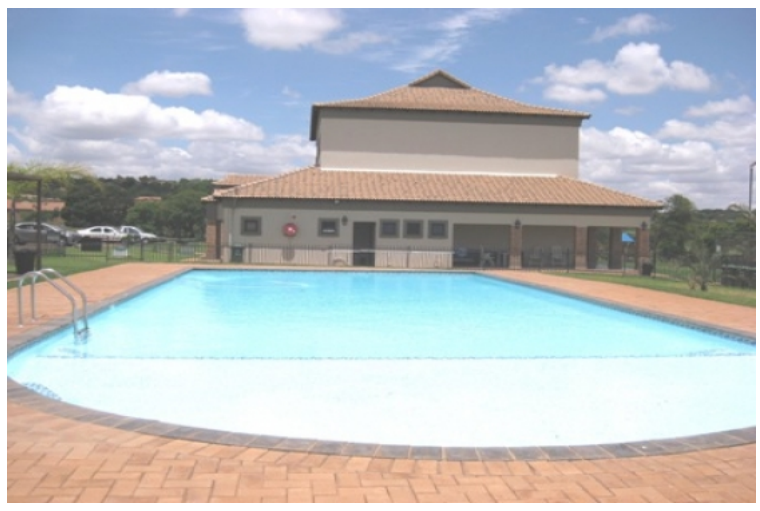

Figure 17: View of the swimming pool with club house at the back (Source: junkmail.co.za)

The perceptions of crime and fear of crime varied compared to those discussed in the relation to the previous six spaces. Respondents in Mooikloof Ridge mentioned that they loved and enjoyed the entertainment area and sports facilities and that it is very popular with children who can safely play there. No alcohol is allowed in the common space, which also tends to contribute to general good behaviour. In The Wilds, respondents enjoyed the facilities, although it may be overcrowded at times. Most of the respondents found the security very appealing. They mentioned that a variety of security features such as access control into the estate and the presence of security guards offered a sense of safety for children to play in the space. It is, therefore, the lack of concern about crime and fear that dominated the discussion in these two spaces.

\section{The implications of changing pub- lic spaces and crime for more inclu- sive cities}

Internationally, it is recognised that the physical environment can influence opportunities for crime and the fear thereof, as promoted by theories of Crime Prevention through Environmental Design (CPTED) (NEWMAN, 1973; POYNER, 1983; COLEMAN, 1985; EKBLOM, 1995 and SHAFTOE, 1996) and Situational Crime Prevention (Clarke 1995). In South Africa, these theories were incorporated in a manual entitled "Designing Safer Communities" for the South African Police Service (SAPS) to promote CPTED in the country through a focus on five principles, namely surveillance and visibility, territoriality, access and escape routes, image and aesthetics and target hardening to reduce opportunities for crime (KRUGER et al, 2001). The presence or absence of these principles can influence the opportunities for crime, as well as the perceptions of safety in specific environments.

This discussion indicated that public space in Pretoria is changing and that these changes influence the opportunities for and fear of crime within the public spaces. This relates to both the form and function of these spaces. The form or nature of the spaces influenced the opportunities of crime in three ways, namely through a lack of lighting, overgrown or dense vegetation and a lack of management and maintenance. The lack of lighting compromised the principle of surveillance and visibility. It is argued that surveillance would allow the casual observance of space by its users and police or other enforcement agents to watch these areas and respond to danger or unlawful activities (KRUGER et al, 2001, p. 33). Visibility, which is the degree to which the environment is made visible through lighting and uninterrupted lines of sight, was reduced through dense vegetation in some of the parks. Furthermore, the lack of management and maintenance compromised the principle of image and aesthetics. The image projected by poorly maintained buildings or public spaces has been linked to the fear of crime, often referred to as "crime and grime" (KRUGER et al, 2001, p. 35). 
In addition to the form, the function or use of the public spaces also influenced the opportunities for crime. Users of the public spaces referred to issues such as the abuse of alcohol and other substances, drug dealing and the presence of homeless people. This also reflects theories on the fear of crime, which indicate that the fear of crime is a product of victimisation, a breakdown of social control and a result of the physical environment (BANISTER and FIFE, 2001). The third aspect directly relates to the theories of CPTED discussed above, where fear of crime is linked to the environment and how people experience and interpret the environment. In this case, fear is embedded in the social and physical characteristics of the environment and the extent to which the individual is familiar and comfortable in the space (BANISTER and FIFE, 2001, p. 809). The presence of drug dealers, people under the influence of drugs or alcohol and homeless people therefore influenced the experience and comfortability of many of the public space users, contributing to the fear of crime. While one would expect law enforcement to deal with drug dealers and those abusing substances, the issue of homelessness is less clear to deal with in a country where more than fifty percent of the population lives below the poverty line and the housing backlog continues to grow. Homelessness remains a serious concern in the City of Tshwane, as indicated by the Homeless Summit of 2015 (Pathways out of Homelessness, 2015). This report also indicated that homeless people often find themselves as victims in public space, either as unwanted citizens or as easy prey for criminals, which often results in fear for the present and the future (Pathways out of Homelessness, 2015). Ironically, fear of the other is therefore present within different groups in public spaces. This reflects what Bauman (2006) has called "liquid modern fears", the name people give to a multitude of uncertainties related to the dangers of the liquid modern age. These uncertainties are often based on ignorance of what the real threat is and the incapacity to determine this (BAUMAN, 2006), resulting in a retreat from citizens to participate in city life as they become paralysed by fear (BAUMAN, 2009).
This creates a dilemma regarding the use of public space. While, in essence, the aim of public space is to serve as "the common ground where people carry out the functional and ritual activities that bind a community" (CARR et al, 1992, cited in MADANIPOUR, 1996, p. 146) and a "space for peaceful coexistence and impersonal encounter" (Walzer, cited in Madanipour 1996, p. 146), this does not always happen in reality. Crime and fear, as well as uncivil behaviour undermine the quality and experience of public space for many users. As a result, some users manage the risk by avoiding these spaces, which contributes to the cycle of decline (CARMONA, 2010). Crime and the fear of crime, therefore, contribute to the retreat from the public realm for those with choice (MIETHE, 1995). As is the case in South Africa, there has been a growing perception in the USA that public spaces are dangerous places and as a result of the fear of crime people started to avoid them. These trends, combined with perceptions of changing and inner city decline, encouraged increasing privatisation (GIDDENS, et al, 2011). Consequently, the last few decades have witnessed many examples of privatisation and the loss of traditional public space through the proliferation of shopping centres and the explosion of gated communities (BANARJEE and LOUKAITES-SIDERIS, 1998; BLAKELY and SNYDER, 1997).

This has also been evident in South Africa. Not only has the response to crime and the fear contributed to the establishment of quasi-public spaces linked to shopping malls, but it has also resulted in the creation of common open spaces for recreation in gated communities, which reflect the principles of target hardening on a larger scale. Target hardening reduces the attractiveness and vulnerability of potential targets through the strengthening of building facades or boundary walls (KRUGER et al, 2001) and, therefore, also refers to the physical strengthening of gated neighbourhoods or estates. This discussion indicated that the people in the two common open spaces in the gated communities enjoyed the same benefits of traditional public spaces, but within a secure and protected environment. However, while it bene- 
fits the residents from these estates, it raises questions about the implications for more inclusive public space.

Carmona (2010) points out that some types of behaviour in space can have an impact on the equitable use of public space. Therefore, due to crime and the fear of crime in traditional public spaces, those who can afford it retreat to gated communities with safer spaces for recreation. Although they still meet people from the estate, the estate excludes people from outside. This reduces the opportunities to meet other people who are not relatives, friends or work associates and to share common ground. In this sense, gated communities have a negative impact on social inclusion and contribute to segregation within cities, albeit segregation between classes and not population groups as in the past. Consequently, residents' daily interactions with people from other social groups diminish substantially and for many people public encounters occur only within protected and homogeneous groups as is also the case in Brazilian cities. The impact can be substantial, as Caldeira (2011) so aptly explains:

In the materiality of segregated spaces, in people's everyday trajectories,[...] in their appropriations of streets and parks, and in their constructions of walls and defensive facades, social boundaries are rigidly constructed. Their crossing is under surveillance. When boundaries are crossed in this type of city, there is aggression, fear and a feeling of unprotectedness; in a word, there is suspicion and danger. Residents of all social groups have a sense of exclusion and restriction. For some, the feeling of exclusion is obvious, as they are denied access to various areas and are restricted to others. Affluent people who inhabit exclusive enclaves also feel restricted; their feelings of fear keep them away from regions and people that their mental maps of the city identify as dangerous (CALDEIRA, 2011, p. 324).

Yet, it is not only gated communities that create exclusion within contemporary cities. Ironically, a public space that was revitalised to serve a former marginalised and poorer community is now locked most of the time due to fear of vandalism. Solomon Mathlangu Square stands as a white elephant in the midst of one of the busiest nodes in Mamelodi and alongside one of the most vibrant pedestrian walkways. The same local authority that spent 36 million Rand to upgrade the space, is now excluding residents from the surrounding communities. Hence, the aim of the upgraded public space to inspire, educate and offer opportunities to the local community has not been fulfilled. They remain marginalised in terms of access to high quality public open space.

This discussion, therefore, shows that common open spaces in gated communities are an attempt to offer residents similar recreational facilities to those that are traditionally associated with public spaces in cities, but with an emphasis on safety and security. The Constitution of South Africa allows both the right to safety and security and access to public space for all. This creates a dilemma in practice as the right to security is often used to justify the presence of various types of gated communities (LANDMAN, 2007). The major challenge, however, is a lack of opportunity and access to safer and welldeveloped spaces for the poorer communities and reduced opportunities for social interaction in public space. Revitalisation of public spaces does not always offer a solution. While it contributed to greater opportunities for residents in Attridgeville, those in Mamelodi are still excluded by the local authority due to a fear of vandalism in the park.

Bearing this in mind, it is important that the planning, design and management of public spaces take into account CPTED principles and interventions that are aimed at greater integration through an integrated approach to crime prevention in the built environment. This includes interventions such as mixed land-use, 24-hour use, celebration of the street/public realm, higher densities through appropriate built form and building typologies, accessible, smaller parks with symbolic rather than actual boundaries, the right psychological signals, appropriate signs, and open and pedestrian friendly sidewalks with entrances on the streets and buildings overlooking the public space (LANDMAN, 2009). From a planning perspective it would be important to look at the size of public spaces in 
South African cities, as well as their location and predominate land uses to address opportunities for crime. This would range from a focus on redeveloping under-developed public spaces in former marginalised areas to the reconsideration of illegal land uses in some of the more developed public spaces. At a design level, it would be important to consider cross-cutting issues such as lighting, landscaping and signage where relevant, for example to ensure a continuous band of lighting or durable light fittings and consider the placement of trees, shrubs and vegetation to keep sightlines clear and allow sufficient lighting. In addition, there are a number of design factors that could influence the opportunities for crime in public spaces related to movement networks, the physical design of these spaces and the detail design of the buildings on and around them. Finally, the management and maintenance factors are also likely to play a key role in reducing opportunities for crime and the fear of crime in public space. Such efforts should also include the homeless in attempts to make parks safer. For example, at the Homeless Summit, a homeless participant openly called for common solutions and collaboration towards addressing homelessness and standing together against crime (Pathways out of Homelessness, 2015)

By utilising CPTED in this way, rather than focussing on target hardening and access control, the focus may over time shift to more diverse and inclusive spaces as advocated by Sennett (2006) and Amin (2008). This may then have the potential to move towards a condition where "the experience of public space remains [or becomes] one of sociability and social recognition and general acceptance of the codes of civic conduct and the benefits of collective public resources" (AMIN, 2014, p. 7-8).

\section{Conclusion}

This article sought to examine the changing form and function of a number of contemporary public spaces in Pretoria and determine the impact thereof on crime and the fear of crime, as well as the implications for inclusive cities in South Africa. This discussion indicated that the nature and use of public spaces are changing in various parts of the city. More traditional public spaces in the inner city and suburbs have been neglected and show signs of degradation. In spite of this, they are still used by many people, although some continuously fear crime within these spaces due to the quality and nature of some of the spaces, as well as the presence of drug dealers and homeless people. Previously underdeveloped spaces in marginalised areas have been revitalised to improve the quality of the built environment and quality of life of people in these areas. While the one example have proven to be mostly successful, although people still fear crime during the night, the other space is locked by the local authority to prevent vandalism and destruction. In response to crime and the fear of crime in the more traditional public spaces, alternative common open spaces have been developed as part of gated communities, where residents can enjoy the recreational benefits without the presence of crime or fear thereof. This, however, raises concerns about the implications of separate, enclosed spaces for more inclusive cities with a history of segregation practices such as in South Africa and Brazil and contemporary policies that promote greater integration and equality.

However, for the significance of the transformation of space and its implications for inclusion to be fully comprehended, it requires a more nuanced reading of the transformation of public space within its broader context. Firstly, there is a need to recognise that levels of crime and fear of crime remain high within South African cities. This also trickles down to people's experiences and perceptions within public space. The discussion indicated that many users of more traditional "open" public spaces portray high levels of fear of crime and even sometimes witnessed criminal behaviour such as substance abuse and drug dealing. Consequently, many of those who can afford it retreat to gated communities where they can recreate in common open spaces without any fear of crime. Therefore, although it does no not imply that there are no other motives driving the demand for gated communities, the search for greater safety and security in protected "public" space does not automatically signify a desire for segregation. In this case, for 
many, segregation becomes a means to an end, where the principle of target hardening is applied to reduce the vulnerability of the residents in the recreational space.

Secondly, however, it does not mean that the implications of such interventions for inclusive cities should be ignored or the fears of other groups such as the homeless people sleeping in many of the parks Post-apartheid policies in South Africa emphasise the need for spatial integration and social inclusion. In addition, the discussion indicated that traditional public spaces are still used and therefore valuable in the city. Consequently, the need for safer spaces should not be ignored and the management and maintenance not be neglected. This implies a need for an integrated approach to crime prevention in the built environment rather than a segregated approach focused on target hardening and access control. It is therefore important that the planning, design and management of public spaces take into account CPTED principles and interventions that are aimed at greater integration. Bearing this in mind, instead of placing an over-emphasis on segregation, the focus should rather be on improving safety and comfort in the traditional open spaces to draw people back and improve the experience of all the users through safety promotion, building trust and reducing the fear of crime.

For those committed to more inclusive cities in South Africa and Brazil, there is a need not only for a temporary tolerance of common spaces in gated communities, but also for a greater commitment to the positive transformation of public spaces in these cities. This means that architects, urban designers and planners need to be more aware of the potential of CPTED approaches to reduce opportunities for crime through the modification of the form of these spaces. It also means that local authorities need to reclaim public space for the benefits of all residents through a combination of law enforcement programmes to deal with criminals and social disorder in these spaces and consider social welfare programmes to assist the homeless to find alternative shelter.
The financial assistance (Grant no. 81213) of the National Research Foundation (NRF) towards the research is hereby acknowledged. Opinions expressed and conclusions arrived at are those of the authors and cannot be attributed to the NRF. The author would also like to thank Darren Nel for the production of the maps and the following students for assistance with data collection in the various case study areas: Nnono Kekane, Nompumelo Maditse, Kundani Makakavhule, Ziningi Mkhize, Kgomotso Malope, Siphiwe Masango, Samukeliswe Ngcobo, Nthabiseng Makomene and Liandra Raats.

\section{References}

AMIN, A. 2008. Collective culture and urban public space, City, 12 (1): 5-24.

BAUMAN, Z. 2006. Liquid Fear. Wiley: London.

BAUMAN, Z. 2009. Trust and Fear in the City. Translated by Eliana Aguiar. Rio de Janeiro. Zorge Ahar Ed.

BANISTER, J. and FIFE, N. 2001. "Introduction: Fear and the City", Urban Studies, Vol. 38, 5 6: $807-813$.

BLAKELY, E.J., and SNYDER, M.G., 1997. Fortress America: Gated Communities in the United States. Washington, D.C.: Brookings Institution Press.

BORNMAN, E. (2006) National symbols and nation-building in the post-apartheid South Africa. International Journal of Intercultural Relations. 30(1), 383-399.

BREETSKE, G., LANDMAN, K. \& COHNE, E. (2014) "Is it safer behind the gates? Crime and gated communities in South Africa", Journal of Housing and the Built Environment, 29(1): 123139.

CALDEIRA, T.P.R. (2000). City of walls: crime, segregation and citizenship in Sao Paulo. Berkeley, University of California Press.

CARMONA, M. 2010. "Contemporary public space: Critique and Classification, Part One:

\section{Acknowledgements}


Critique", Journal of Urban Design, 15 (1): 123148.

CLARK, R.V. 1995. "Situational Crime Prevention", in Tonnry, M. and Farrington, D. (eds) Building a Safer Society: Strategic Approaches to Crime Prevention. Chicago: University of Chicago Press.

COLEMAN, A., 1985. Utopia on Trial: Vision and Reality in Planned Housing. London: Hilary Shipman.

DE KOCK, C. (2015) The 2014/2015 Crime Statistics - hope or despair, Servamus, 13, pp. 10-13.

DE MESQUITA NETO P, 'Crime, violence and political uncertainty in Brazil'. Paper presented at the Conference 'Crime and Policing in Transition: Comparative Perspectives', at the South African International Affairs, Johannesburg, South Africa, 30 August-1 September 2001.

EKBLOM, P 1995. "Less Crime by Design" in Annals of the American Academy of Political and Social Science

GIDDINGS, B., CHARLTON, J. and HORNE, M. 2011. Public squares in European city centres. Urban Design International, 16 (3): 202-212.

KRUGER, T., LANDMAN, K., and LIEBERMANN, S., 2001. Safer by design: a manual for crime prevention through planning and design. Pretoria: CSIR Publication.

KOWARICK L, 2001. Urban Spoliation, Social Struggles and Citizenship: Aspects of Our Recent History. Paper of the University of São Paulo, São Paulo, Brazil.

LANDMAN, K., (2003). 'Crime, political transition and spatial transformation in Brazil and South Africa'. South African Institute for International Affairs (SAllA) Report 35, Johannesburg, SAllA Publication.

LANDMAN, K. (2005) Op zoek naar veiligheid in Tshwane. Agora, 21 (5), pp. 35 - 37.

LANDMAN, K. 2006 "Who owns the roads? Privatising public space in South African cities through neighbourhood closures", in GeoJournal, 66(1), pp. $133-146$.

LANDMAN, K. 2016. "Shopping malls with quasi-public spaces in Pretoria: Neo-traditional consumption space or controlled village commons?", South African Journal of Town and Regional Planning, 69: 20-32.

LANDMAN, K. 2016. "The transformation of urban space in South Africa and the role of urban design", Urban Design International, 21, 7892 (Spring 2016) | doi:10.1057/udi.2015.24.

LANDMAN, K. and BADENHORST, W. 2014 "Gated communities and spatial transformation in Greater Johannesburg", Changing space, changing city: Johannesburg after apartheid, Harrison, P., Gotz, G., Todes, A. and Wray, C. (eds).Johannesburg: WITS University Press, pp. 215-229.

LEMANSKI, C., LANDMAN, K. and DURRINGTON, M. 2008. "Divergent and similar experiences of 'gating' in South Africa: Johannesburg, Durban and Cape Town" Urban Fo$\begin{array}{lll}\text { rum, } & 19 & \text { (2):133-158 }\end{array}$ http://researchspace.csir.co.za/ dspace/handle/10204/2626

MADANIPOUR, A. 1996. Design of Urban Space: and inquiry into a Socio-Spatial Process. Chichester: John Wiley.

MIETHE, T. 1995. Fear and withdrawal from urban life, Annals of the American Society of Political and Social Science, No. 539, pp. 1427.

New Fitness Park, 2013, Thswane Service Publication,

http://www.servicepublication.co.za/articles/newfitness-park-9407.html

NEWMAN, O. 1973. Architectural Design for Crime Prevention. US Department of Justice, Law Enforcement Assistance Administration and National Institute of Law Enforcement and Criminal Justice.

Pathways out of Homelessness: Research Report 2015. Accessed online 18 Sept 2017 at 
www.up.ac.za/media/shared/249/ZP_Files/home lessness-report-2015.zp70613.pdf

POYNER, B., 1983. Design against Crime- Beyond defensible space. London: Butterworths.

SENNETT, R. 2006. "The open city", Urban Age. London: Cities Programme, London School of Economics and Political Science.

SHAFTOE, H. 1996. "Planning for crime prevention" in Greed, C. and M. Roberts (eds.) Introducing Urban Design: Interventions and Responses. Longman Publishers, 178 -187.

SHAW, M., (2002). Democracy's Disorder? Crime, Police and Citizen Responses in Transitional Societies. Johannesburg: SAllA Publication.

Solomon Mathlangu Square in Pretoria gets R36m make-over, 2015, Property News, http://www.eprop.co.za/commercial-propertynews/item/19027-solomon-mahlangu-square-inpretoria-gets-r36m-make-over.html

TUROK, I. and BOREL-SALADIN, J. 2014. Is urbanisation in South Africa on a sustainable trajectory? Development Southern Africa, 13(5): 675-691. 